\title{
Discovery of a Potent and Orally Efficacious TGR5 Receptor Agonist
}

Sameer Agarwal,* Amit Patil, Umesh Aware, Prashant Deshmukh, Brijesh Darji, Santosh Sasane, Kalapatapu V. V. M. Sairam, Priyanka Priyadarsiny, Poonam Giri, Harilal Patel, Suresh Giri, Mukul Jain, and Ranjit C. Desai

Zydus Research Centre, Cadila Healthcare Ltd., Sarkhej-Bavla N.H. No. 8 A, Moraiya, Ahmedabad 382 210, India

Supporting Information

ABSTRACT: TGR5 is a $G$ protein-coupled receptor (GPCR), activation of which promotes secretion of glucagon-like peptide-1 (GLP-1) and modulates insulin secretion. The 2 -thio-imidazole derivative $\mathbf{6 g}$ was identified as a novel, potent, and selective TGR5 agonist ( $\mathrm{hTGR5} \mathrm{EC}_{50}=$ $57 \mathrm{pM}$, mTGR5 $=62 \mathrm{pM}$ ) with a favorable pharmacokinetic profile. The compound $6 \mathrm{~g}$ was found to have potent glucose lowering effects in vivo during an oral glucose tolerance test in DIO C57 mice with $\mathrm{ED}_{50}$ of $7.9 \mathrm{mg} / \mathrm{kg}$ and $\mathrm{ED}_{90}$ of $29.2 \mathrm{mg} /$ $\mathrm{kg}$.

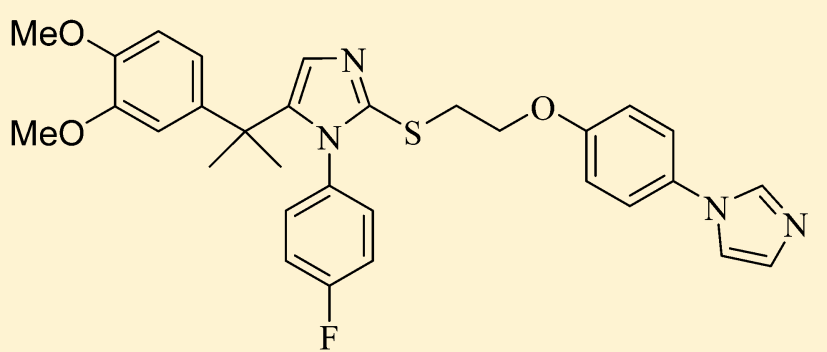

$6 \mathrm{~g}$

KEYWORDS: TGR5, TGR5 agonist, GPR 131, GPBAR1, GLP1 secretion, diabetes

$\mathrm{D}$ iabetes is increasing globally at an alarming state. ${ }^{1}$ Type 2 diabetes is characterized by reduced insulin sensitivity combined with impaired insulin secretion resulting in higher blood glucose levels. ${ }^{2-4}$ Although a range of therapies are available such as sulfonylureas, metformin, and glinides, ${ }^{5,6}$ they are unable to achieve satisfactory glycemic control. Therefore, there is an urgent need for research exploring therapies with distinct unprecedented mechanisms of action.

Takeda G-protein-coupled receptor 5 (TGR5), also known as GPR 131, GPBAR1, or M-BAR is G protein-coupled receptor primarily expressed in monocytes and macrophages, lung, spleen, and the intestinal tract, and it is activated by bile acids. ${ }^{7,8}$ It has been suggested that bile acids induce glucagonlike peptide-1 (GLP-1) secretion from primary intestinal enteroendocrine cells by increasing intracellular cAMP levels via the TGR5 receptor." 9 Additionally, activation of TGR5 receptors in brown adipose tissue has been proposed to increase energy expenditure through the induction of type 2 iodothyronine deiodinase (D2). ${ }^{11}$ Thus, a small molecule TGR5 agonist may be beneficial for the treatment of type 2 diabetes with simultaneous management of glucose levels, body weight, and associated complications.

A wide range of structurally diverse modulators of TGR5 have been reported in the literature by various pharmaceutical companies (Figure 1a). ${ }^{12-22}$ Most of these reported TGR5 agonists, however, possess insufficient potency and/or lack metabolic stability. This communication describes the discovery of 2-((2-(4-(1H-imidazol-1-yl)phenoxy)ethyl) thio)-5-(2-(3,4dimethoxyphenyl) propan-2-yl)-1-(4-fluoro phenyl)-1H-imidazole $(6 \mathrm{~g})$, a potent, selective, and orally efficacious TGR5 agonist. a.

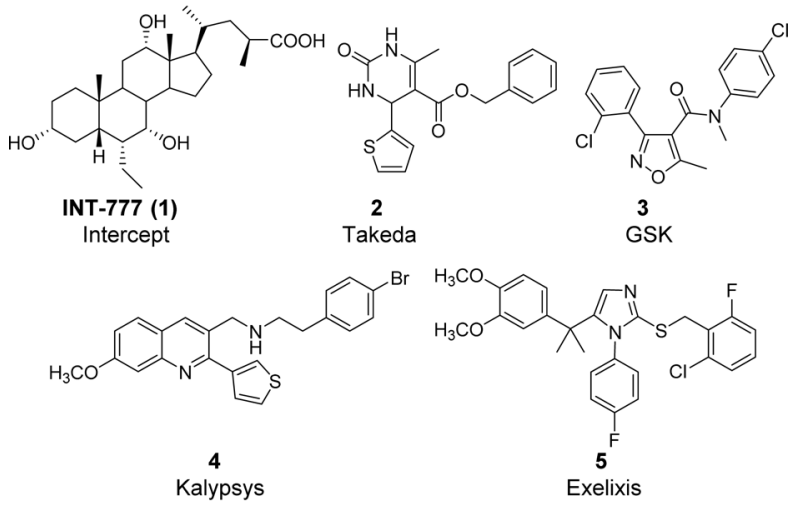

b.

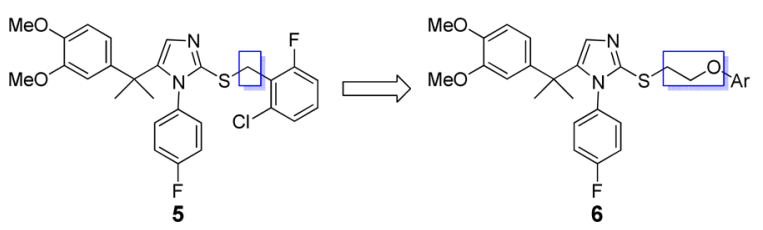

Figure 1. (a) Selected bile acid and nonbile acid TGR5 receptor agonist reported in literature. (b) Schematic representation of ligand optimization.

The Exelixis compound $\mathbf{5}$ showed good potency, although with a modest pharmacokinetic profile, and thus represented an

Received: August 10, 2015

Accepted: November 20, 2015

Published: November 20, 2015 
attractive starting point for generating novel TGR5 agonists. Several modeling studies of TGR5 have been published. ${ }^{23,24}$ A TGR5 receptor homology model was generated, which provided insight regarding the binding site and binding site residues. Modeling studies show that the van der Waals surface of the active site of TGR5 receptor has a narrow channel extending from the terminal aryl group of $\mathbf{5}$ to a hollow opening near the extracellular loop between TM4 and TM5 (refer Supporting Information). Thus, it was hypothesized that, a linker, perhaps with a hydrogen bond acceptor such as oxygen atom, that fits suitably in the narrow channel and provides conformational flexibility and positional adaptability, would be beneficial. Keeping this in view a linker was attached to 5, which provided 6 (Figure 1b). Moreover, further substitution on the terminal phenyl ring of $\mathbf{6}$ may also provide an opportunity for potential hydrogen bonds or $\pi-\pi$ interactions.

Accordingly, several compounds were designed and synthesized, and their activity data was used to build a structureactivity relationship (SAR) profile (Table 1). The 2-thioimidazole derivatives (6) were synthesized as depicted in Scheme 1.

Synthesis of 6 began with the dimethylation of commercially available 2-(3,4-dimethoxyphenyl) acetonitrile (7) followed by selective reduction of cyano group with diisobutylaluminum hydride (DIBAL) to produce the aldehyde 9. ${ }^{25}$ Treatment of 9 with methylmagnesium bromide followed by oxidation of the resulting alcohol 10 under Swern condition afforded 11, which in turn was brominated using tetrabutyl ammoniumtribromide to afford 12. Further transformation of $\mathbf{1 2}$ under Delépine reaction conditions gave amine 13 as its corresponding hydrobromide salt, which on treatment with 1-fluoro-4isothiocyanatobenzene provided the thiourea derivative 14 . The construction of the imidazole skeleton is achieved via cyclization of 14 in boiling acetic acid to give the 2-mercapto imidazole derivative 15. Finally, alkylation with excess of 1,2dibromoethane gave the advanced intermediate 16 , which on further alkylation with substituted phenol afforded the test compounds $\mathbf{6 a}-\mathbf{6 1}$ in good yields and high chemical purity. ${ }^{26}$

The compounds were evaluated for their ability to activate TGR5 using luciferase-based reporter gene assays. Consistent with our hypothesis, extension of the side chain was helpful and the compound $6 \mathrm{a}$ was found to be potent $\left(\mathrm{EC}_{50}=38 \mathrm{nM}\right)$. We then turned our attention to optimize substitution on the terminal phenyl ring. The compounds $\mathbf{6} \mathbf{b}$ exhibited $\mathrm{EC}_{50}$ of 2.3 $\mathrm{nM}$, indicating that substitution on the terminal phenyl ring was preferred. However, $6 \mathbf{b}$ was very lipophilic ( $\log \mathrm{P}=7.2)$. Thus, incorporation of polar heterocycles at C-4 position was investigated. The compound $\mathbf{6 c}$, having pyrrole group, displayed potent TGR5 agonistic activity as compared to $\mathbf{6 a}$. The 4-pyrrole derivative $6 \mathrm{c}$ was an agonist with $\mathrm{EC}_{50}$ of $7.8 \mathrm{nM}$, indicating that introduction of nitrogen containing heterocycle may induce a positive influence on the activity. Therefore, pyrazole and triazole rings were substituted at C-4 position to further probe the SAR. The pyrazole (6d) and triazole (6e) derivatives were found to be nearly equipotent. The thiazole analogue $6 \mathrm{f}\left(\mathrm{EC}_{50}=31.5 \mathrm{nM}\right)$ was found to be less potent than compounds 6c, 6d, and 6e. These results indicated that carbon-nitrogen bond for introduction of terminal heterocyclic group might be beneficial to increase the binding affinity of the compounds; however, carbon-carbon linkage might not favor this. Further optimization led to the discovery of many potent compounds and compound $6 \mathrm{~g}$ with a polar C-4 imidazole substituent was identified as most potent TGR5 agonist $\left(\mathrm{EC}_{50}\right.$
Table 1. In Vitro Activity of Reference Compound (5) and Compounds $6 a-61^{a}$

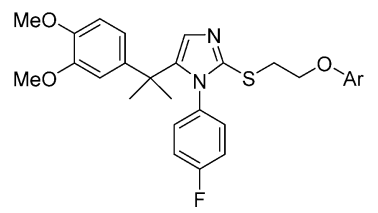

\begin{tabular}{|c|c|c|c|}
\hline Compound & $\mathrm{Ar}$ & $\begin{array}{c}\text { hTGR5 } \\
\mathrm{EC}_{50}(\mathrm{nM}) \\
\end{array}$ & $C \operatorname{Cog} \mathrm{P}^{\mathrm{b}}$ \\
\hline 5 & 5, Exelixis & 17.08 & 7.96 \\
\hline $6 a$ & & 38 & 7.17 \\
\hline $6 b$ & & 2.3 & 7.2 \\
\hline $6 c$ & & 7.8 & 7.56 \\
\hline $6 d$ & & 19.6 & 7.17 \\
\hline $6 e$ & & 16.8 & 6.72 \\
\hline $6 f$ & & 31.5 & 7.96 \\
\hline $6 \mathrm{~g}$ & & 0.057 & 6.37 \\
\hline $6 h$ & & 1.48 & 7.04 \\
\hline $6 i$ & & 5.8 & 6.53 \\
\hline $6 \mathbf{j}$ & & 8.6 & 7.2 \\
\hline $6 k$ & & $>100$ & 6.71 \\
\hline 61 & & $>100$ & 6.33 \\
\hline
\end{tabular}

${ }^{a} \mathrm{EC}_{50}$ values given are expressed as mean \pm SEM of three independent experiments; mean standard deviation is $\pm 16 \%$. ${ }^{b}$ Calculated from ChemBioDraw Ultra 12.0 by CambridgeSoft.

$=57 \mathrm{pM})$ with reduced cLog $\mathrm{P}$ value compared to compounds 6c-6e. To explore possibilities for further structural optimization, we focused our investigation to the substituents of $6 \mathrm{~g}$. Introduction of several substituents at the terminal part of the molecule indicated that a variety of groups were well tolerated at this position. However, these substituents did not improve potency compared to $6 \mathrm{~g}$ (compounds $6 \mathbf{h}-6 \mathbf{j}$ ). These data suggest that possibly both lipophilicity and electronics play key roles in the activity for this class of compounds. Compounds with fused heterocyclic systems (6k and 61) were poor agonists suggesting that fused systems hindered the receptor compound interaction.

The most potent compound $\mathbf{6 g}$ was docked into the putative binding pocket in the TGR5 homology model (Figure 2). The ligand binding site in TGR5 is hydrophobic, and Tyr 240 appears to be an important amino acid that stabilizes the ligand 
Scheme 1. Synthesis of Compound $6^{a}$<smiles>COc1ccc(CC#CCCCCCC(C)(C)c2ccc(OC)c(OC)c2)cc1OC</smiles><smiles>COc1ccc(C(C)(C)C(=O)CBr)cc1OC</smiles>

10

11

12
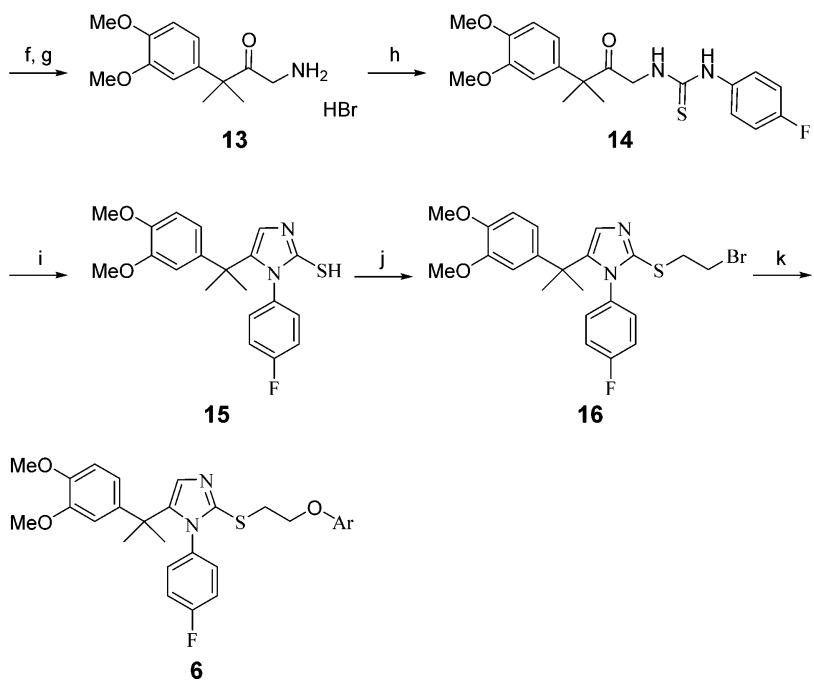

${ }^{a}$ Reagent and conditions: (a) MeI, NaH, THF, $0{ }^{\circ} \mathrm{C}$ to r.t., 3 h, 93\%; (b) DIBAL, toluene, $-78{ }^{\circ} \mathrm{C}, 2 \mathrm{~h}, 93 \%$; (c) $\mathrm{MeMgBr}$, dry $\mathrm{Et}_{2} \mathrm{O}, 0{ }^{\circ} \mathrm{C}$ to r.t., $80 \%$; (d) oxalyl chloride, $\mathrm{DMSO}, \mathrm{Et}_{3} \mathrm{~N}, \mathrm{DCM},-78{ }^{\circ} \mathrm{C}, 2 \mathrm{~h}$, 82\%; (e) $\mathrm{Bu}_{4} \mathrm{NBr}_{3}, \mathrm{DCM}, \mathrm{MeOH}, 0{ }^{\circ} \mathrm{C}$ to r.t., 7 h, $100 \%$; (f) HMTA, DCM, r.t., 48 h; (g) EtOH, $\mathrm{HCl}, 80{ }^{\circ} \mathrm{C}, 3 \mathrm{~h}$; (h) 1-fluoro-4isothiocyanatobenzene, $\mathrm{Et}_{3} \mathrm{~N}, \mathrm{DCM}, 0{ }^{\circ} \mathrm{C}$ to r.t., $1 \mathrm{~h}, 42 \%$; (i) AcOH, $118{ }^{\circ} \mathrm{C}, 3 \mathrm{~h}, 73 \%$; (j) 1,2-dibromoethane, $\mathrm{K}_{2} \mathrm{CO}_{3}$, acetone, r.t., 2 h, $73 \%$; (k) substituted phenol, $\mathrm{K}_{2} \mathrm{CO}_{3}, \mathrm{DMF}, 90{ }^{\circ} \mathrm{C}, 3-5 \mathrm{~h}$.

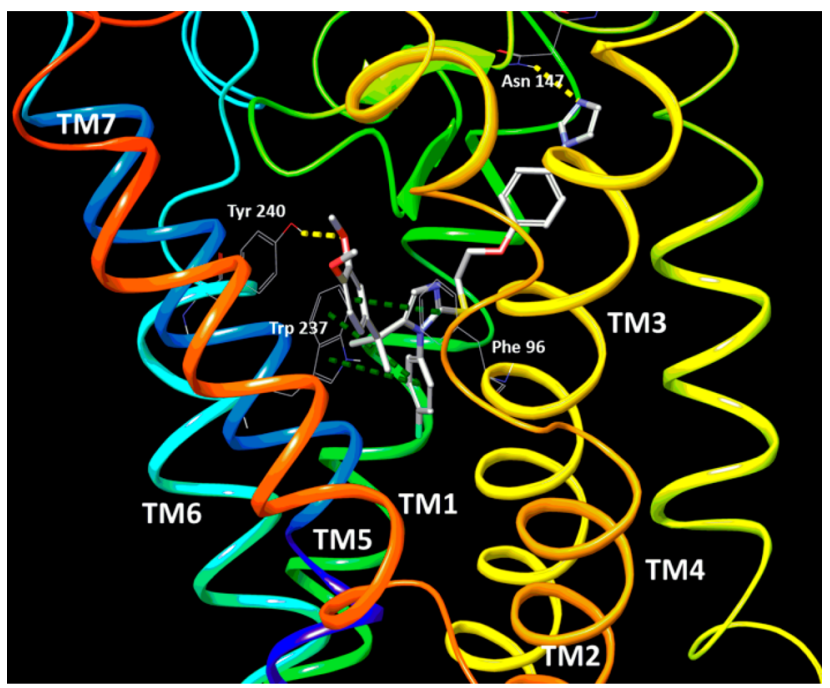

Figure 2. Binding mode of $\mathbf{6 g}$ in homology model of TGR5 receptor.

through H-bond interactions and aromatic stacking interactions. 3,4-Dimethoxyphenyl group of ligand has $\mathrm{OH} \cdots \mathrm{O}$ interaction between the oxygen of the meta-methoxy and the hydroxy of Tyr 240. This group also forms $\pi-\pi$ stacking interaction with Phe 96. The fluoro-phenyl group also shows $\pi-\pi$ stacking interaction with $\operatorname{Trp} 237$, which nicely fits in the bottom pocket and perhaps adds to the stability. The distance between sulfur and the farthest aromatic carbon is $\sim 5.5 \AA$ in compound 5 and is $\sim 10.5 \AA$ in compound $6 \mathrm{~g}$. The high potency of $\mathbf{6 g}$ suggests that extension of side chain into the channel leading to the exterior might play an important role in modulating biological activity. Notably, it was found that the $\mathrm{N}$ 3 nitrogen atom of the terminal C-4 imidazole group of $6 \mathrm{~g}$ is involved in hydrogen-bonding interactions with Asn 147 of the extra cellular loop between TM4 and TM5. This may stabilize the conformations and may be crucial in the activation of TGR5. However, such hydrogen-bonding interaction was not observed with compounds $\mathbf{6 c}, \mathbf{6 d}$, and $\mathbf{6 e}$. This modeling study proposed that $\mathbf{6 g}$ exerts its TGR5 activity by effectively utilizing a number of different interactions.

Furthermore, compound $\mathbf{6 g}$ showed dose-dependent activation of a cAMP responsive element-driven luciferase reporter in TGR5 overexpressing CHO K1 cells $\left(\mathrm{EC}_{50}=14 \mathrm{nM}\right)$. Additionally, it modulated GLP-1 secretion in vitro at 10 and $30 \mu \mathrm{M}$ concentration in NCI-H716 cells (refer Supporting Information). Many bile acid-derived TGR5 agonists are known to activate the nuclear bile acid receptor FXR (Farnesoid X Receptor); ${ }^{13}$ compound $6 \mathrm{~g}$ exhibited good selectivity against FXR (FXR coactivator functional assay $\left.\mathrm{EC}_{50}=6.4 \mu \mathrm{M}\right)$. Recent reports have shown that TGR5 activation decreases pro-inflammatory cytokine production by cyclic AMP-mediated inhibition of NF- $\kappa \mathrm{B}$ signaling. ${ }^{27}$ Consistent with this, $6 \mathrm{~g}$ showed a dose-dependent inhibition of TNF- $\alpha$ in an LPS-induced cytokine release assay in human whole blood, similar to prednisolone $\left(\mathrm{IC}_{50}=251 \mathrm{nM}\right)$. It has long been a challenge to discover a TGR5 agonist that is potent against both the human and mouse receptor, ${ }^{15}$ albeit, recent literature $^{19}$ described potent compounds active in both receptors. Importantly here, compound $\mathbf{6 g}$ displayed excellent potency on mTGR5 $\left(\mathrm{EC}_{50}=62 \mathrm{pM}\right)$, similar to its potency on hTGR5; this enabled its evaluation in an in vivo mouse model of efficacy.

The physicochemical properties of $\mathbf{6 g}$ suggested that it had suitable drugability properties and potential for in vivo validation (MW 559; experimental cLog $\mathrm{P}=4.7$; good solubility profile). A comparison of the in vivo pharmacokinetic properties of the compound $\mathbf{5}$ and our lead candidate $\mathbf{6 g}$ (Table 2) shows that $\mathbf{6 g}$ has substantially better oral exposure and bioavailability compared to compound 5 . Introduction of the C-4 imidazole group was not only beneficial for potency but

Table 2. Pharmacokinetics Properties of 5 and $6 \mathrm{~g}^{a}$

\begin{tabular}{|c|c|c|c|}
\hline \multirow{2}{*}{$\frac{\text { parameters }}{\text { species }}$} & \multirow{2}{*}{$\frac{5}{\text { mouse }}$} & \multicolumn{2}{|r|}{$6 \mathrm{~g}$} \\
\hline & & mouse & rat \\
\hline PO dose, $\mathrm{mg} / \mathrm{kg}$ & 3 & 3 & 3 \\
\hline$C_{\max }(\mathrm{ng} / \mathrm{mL})$ & 51.75 & 788.84 & $147.71 \pm 72.53$ \\
\hline $\operatorname{AUC}(\mathrm{ng} \cdot \mathrm{h} / \mathrm{mL})$ & 73.48 & 754.21 & $207.13 \pm 98.15$ \\
\hline i.v. dose, mg/kg & 1 & 1 & 1 \\
\hline$V_{\mathrm{dss}}(\mathrm{L} / \mathrm{kg})$ & 1.54 & 0.83 & $2.05 \pm 0.97$ \\
\hline $\mathrm{Cl}(\mathrm{mL} / \mathrm{min} / \mathrm{kg})$ & 45.52 & 47.28 & $79.73 \pm 30.92$ \\
\hline$T_{1 / 2}$, iv (h) & 0.76 & 0.33 & $0.32 \pm 0.05$ \\
\hline$\% F$ & 7 & 71 & 31 \\
\hline
\end{tabular}

${ }^{a}$ Rat PK data is mean $\pm \mathrm{SD}, n=4$. Mouse PK data is mean data because of composite study design, $n=3 /$ time point. Formulation: PO, $0.5 \%$ Tween $80+99.5 \%(0.5 \%)$ sodium-CMC in water; IV, $10 \%$ $\mathrm{NMP}+10 \%$ solutol $+80 \%$ normal saline. 
also improved pharmacokinetic profile relative to $\mathbf{5}$, probably due to better permeability and solubility (Supporting Information). The plasma protein binding (PPB) of compound $6 \mathrm{~g}$ was determined to be very high (99.5 to $99.9 \%$ in rodents). ${ }^{28}$

Having identified a compound with high potency and excellent pharmacokinetic profile, $\mathbf{6} \mathbf{g}$ was evaluated for in vivo GLP-1 secretion in C57 mice. A single oral administration of $6 \mathrm{~g}$ at $30 \mathrm{mg} / \mathrm{kg}$ dose increased plasma GLP-1 levels by 3.8 -fold with respect to vehicle control (Figure 3a). It is noteworthy to

\section{a.}

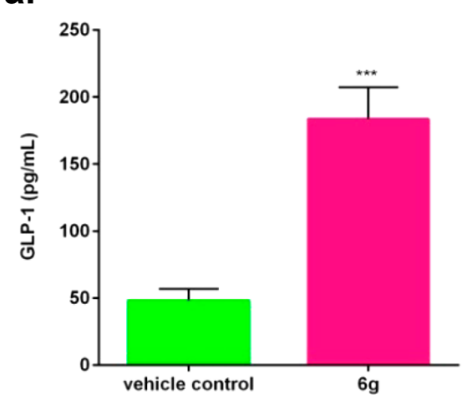

b.

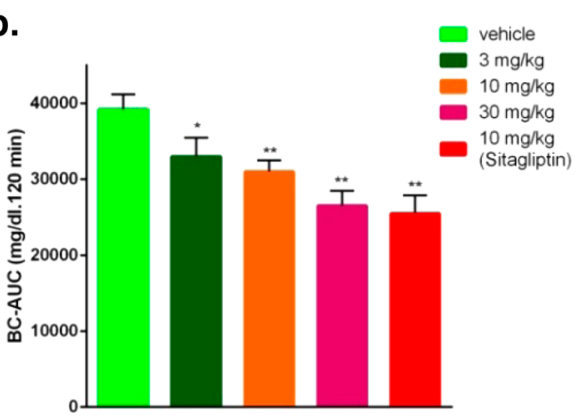

Figure 3. (a) In vivo GLP-1 secretion study of $\mathbf{6 g}$ in C57 $(n=4$ animals/group; female C57 mice; po $30 \mathrm{mg} / \mathrm{kg}$; formulation, $5 \%$ Tween $20+0.5 \%$ sodium CMC $(95 \%) ; * * * P<0.001$ versus control; error bar indicates SEM). (b) In vivo efficacy of $6 \mathrm{~g}$ in DIO C57 mice $(n=4$ animals/group; formulation, $5 \%$ Tween $20+0.5 \%$ sodium CMC (95\%); *P<0.05; **P $<0.005$ versus control; error bar indicates SEM).

mention that significant improvement in portal GLP-1 secretion was observed with $6 \mathrm{~g}$ administration without coadministration of DPP-IV inhibitor. Based on the favorable GLP-1 secretion results compound $6 \mathrm{~g}$ was evaluated for in vivo efficacy by an oral glucose tolerance test (OGTT) in DIO C57 mice. $^{29,30}$ Single oral doses of $\mathbf{6 g}$ robustly lowered the blood glucose excursion (Figure $3 \mathrm{~b}$ ) in a dose-proportional manner from 3 to $30 \mathrm{mg} / \mathrm{kg}$ with an $\mathrm{ED}_{50}$ of $7.9 \mathrm{mg} / \mathrm{kg}$ and $\mathrm{ED}_{90}$ of $29.2 \mathrm{mg} / \mathrm{kg}$, consistent with our finding of elevated plasma GLP-1 levels. Additionally, initial cardiovascular safety studies of $6 \mathrm{~g}$ in telemetered Wistar rats indicated no treatmentdependent changes in heart rate and blood pressure, up to 300 $\mathrm{mg} / \mathrm{kg}$ doses (po). In this study, the free drug exposure was found to be $231.38 \mathrm{ng} \cdot \mathrm{h} / \mathrm{mL}$, which is approximately 90 -fold higher than the efficacy dose exposure, consequently, providing good safety margin.

In conclusion, we have discovered $6 \mathrm{~g}$, a potent and selective TGR5 agonist, which shows GLP-1 secretion and glucose lowering effects in animal models, along with a favorable pharmacokinetic profile. A detailed description of the pharmacodynamics and safety evaluations of $6 \mathrm{~g}$ will be reported in due course.

\section{ASSOCIATED CONTENT}

\section{Supporting Information}

The Supporting Information is available free of charge on the ACS Publications website at DOI: 10.1021/acsmedchemlett.5b00323.

Experimental procedures and analytical data (PDF) Spectra (PDF)

\section{AUTHOR INFORMATION}

\section{Corresponding Author}

*Fax: +91-2717-665355. Tel: +91-2717-665555. E-mail: sameeragarwal@zyduscadila.com or sameer_ag@yahoo.com.

Notes

The authors declare no competing financial interest.

\section{ACKNOWLEDGMENTS}

Authors thank Mr. Jeevan Kumar for modeling studies, Mr. Vishwanath Pawar for safety pharmacology studies, and the management of Zydus Research Centre, Cadila Healthcare Ltd. for support and encouragement. ZRC Communication No. 471.

\section{ABBREVIATIONS}

GPCR, G protein-coupled receptor; BAs, bile acids; CA, cholic acid; LCA, lithocholic acid; FXR, farnesoid X receptor; cAMP, cyclic adenosine monophosphate; CMC, carboxymethylcellulose; NMP, N-methyl-2-pyrrolidone; T2D, type II diabetes; SAR, structure-activity relationship; $\mathrm{PPB}$, plasma protein binding; MW, molecular weight; TM, trans membrane

\section{REFERENCES}

(1) IBD Diabetes Atlas, 6th ed.; International Diabetes Federation: Brussells, Belgium, 2013; http://www.diabetesatlas.org.

(2) De Fronzo, R. A. From the Triumvirate to the Ominous Octet: A New Paradigm for the Treatment of Type 2 Diabetes Mellitus. Diabetes 2009, 58, 773-795.

(3) Nazimek-Siewniak, B.; Moczulski, D.; Grzeszczak, W. Risk of macrovascular and microvascular complications in Type 2 diabetes Results of longitudinal study design. J. Diabetes Complications 2002, 16, 271-276.

(4) Kles, K. A.; Vinik, A. I. Pathophysiology and treatment of diabetic peripheral neuropathy: The case for diabetic neurovascular functions as an essential component. Curr. Diabetes Rev. 2006, 2, 131-145.

(5) Doyle, M. E.; Egan, J. M. Pharmacological agents that directly modulate insulin secretion. Pharmacol. Rev. 2003, 55, 105-131.

(6) Ashiya, M.; Smith, R. E. T. Non-insulin therapies for type 2 diabetes. Nat. Rev. Drug Discovery 2007, 6, 777-778.

(7) Maruyama, T.; Miyamoto, Y.; Nakamura, T.; Tamai, Y.; Okada, H.; Sugiyama, E.; Itadani, H.; Tanaka, K. Identification of membranetype receptor for bile acids (M-BAR). Biochem. Biophys. Res. Commun. 2002, 298, 714-719.

(8) Tiwari, A.; Maiti, P. TGR5: an emerging bile acid G-proteincoupled receptor target for the potential treatment of metabolic disorders. Drug Discovery Today 2009, 14, 523-530.

(9) Katsuma, S.; Hirasawa, A.; Tsujimoto, G. Bile acids promote glucagon-like peptide-1 secretion through TGR5 in a murine enteroendocrine cell line STC-1. Biochem. Biophys. Res. Commun. 2005, 329, 386-390.

(10) Thomas, C.; Gioiello, A.; Noriega, L.; Strehle, A.; Oury, J.; Rizzo, G.; Macchiarulo, A.; Yamamoto, H.; Mataki, C.; Pruzanski, M.; 
Pellicciari, R.; Auwerx, J.; Schoonjans, K. TGR5-mediated bile acid sensing controls glucose homeostasis. Cell Metab. 2009, 10, 167-177. (11) Watanabe, M.; Houten, S. M.; Mataki, C.; Christoffolete, M. A.; Kim, B. W.; Sato, H.; Messaddeq, N.; Harney, J. W.; Ezaki, O.; Kodama, T.; Schoonjans, K.; Bianco, A. C.; Auwerx, J. Bile acids induce energy expenditure by promoting intracellular thyroid hormone activation. Nature 2006, 439, 484-489.

(12) Gioiello, A.; Rosatelli, E.; Nuti, R.; Macchiarulo, A.; Pellicciari, R. Patented TGR5 modulators: A review (2006-present). Expert Opin. Ther. Pat. 2012, 22, 1399-1414.

(13) Pellicciari, R.; Gioiello, A.; Macchiarulo, A.; Thomas, C.; Rosatelli, E.; Natalini, B.; Sardella, R.; Pruzanski, M.; Roda, A.; Pastorini, E.; Schoonjans, K.; Auwerx, J. Discovery of $6 \alpha$-Ethyl-23(S)methylcholic Acid (S-EMCA, INT-777) as a Potent and Selective Agonist for the TGR5 Receptor, a Novel Target for Diabesity. J. Med. Chem. 2009, 52, 7958-7961.

(14) Evans, K. A.; Budzik, B. W.; Ross, S. A.; Wisnoski, D. D.; Jin, J.; Rivero, R. A.; Vimal, M.; Szewczyk, G. R.; Jayawickreme, C.; Moncol, D. L.; Rimele, T. J.; Armour, S. L.; Weaver, S. P.; Griffin, R. J.; Tadepalli, S. M.; Jeune, M. R.; Shearer, T. W.; Chen, Z. B.; Chen, L.; Anderson, D. L.; Becherer, J. D.; De Los Frailes, M.; Colilla, F. J. Discovery of 3-aryl-4-isoxazolecarboxamides as TGR5 receptor agonists. J. Med. Chem. 2009, 52, 7962-7965.

(15) Herbert, M. R.; Siegel, D. L.; Staszewski, L.; Cayanan, C.; Banerjee, U.; Dhamija, S.; Anderson, J.; Fan, A.; Wang, L.; Rix, P.; Shiau, A. K.; Rao, T. S.; Noble, S. A.; Heyman, R. A.; Bischoff, E.; Guha, M.; Kabakibi, A.; Pinkerton, A. B. Synthesis and SAR of 2-aryl3-aminomethylquinolines as agonists of the bile acid receptor TGR5. Bioorg. Med. Chem. Lett. 2010, 20, 5718-5721.

(16) Budzik, B. W.; Evans, K. A.; Wisnoski, D. D.; Jin, J.; Rivero, R. A.; Szewczyk, G. R.; Jayawickreme, C.; Moncol, D. L.; Yu, H. Synthesis and structure-activity relationships of a series of 3-aryl-4-isoxazolecarboxamides as a new class of TGR5 agonists. Bioorg. Med. Chem. Lett. 2010, 20, 1363-1367.

(17) Futatsugi, K.; Bahnck, K. B.; Brenner, M. B.; Buxton, J.; Chin, J. E.; Coffey, S. B.; Dubins, J.; Flynn, D.; Gautreau, D.; Guzman-Perez, A.; Hadcock, J. R.; Hepworth, D.; Herr, M.; Hinchey, T.; Janssen, A. M.; Jennings, S. M.; Jiao, W.; Lavergne, S. Y.; Li, B.; Li, M.; Munchhof, M. J.; Orr, S. T. M.; Piotrowski, D. W.; Roush, N. S.; Sammons, M.; Stevens, B. D.; Storer, G.; Wang, J.; Warmus, J. S.; Wei, L.; Wolford, A. C. Optimization of triazole-based TGR5 agonists towards orally available agents. MedChem Comm 2013, 4, 205-210.

(18) Piotrowski, D. W.; Futatsugi, K.; Warmus, J. S.; Orr, S. T. M.; Freeman-Cook, K. D.; Londregan, A. T.; Wei, L.; Jennings, S.; Herr, M.; Coffey, S. B.; Jiao, W.; Storer, G.; Hepworth, D.; Wang, J.; Lavergne, S. Y.; Chin, J. E.; Hadcock, J. R.; Brenner, M. B.; Wolford, A. C.; Janssen, A. M.; Roush, N. S.; Buxton, J.; Hinchey, T.; Kalgutkar, A. M.; Sharma, R.; Flynn, D. A. Identification of Tetrahydropyrido[4,3d]pyrimidine Amides as a New Class of Orally Bioavailable TGR5 Agonists. ACS Med. Chem. Lett. 2013, 4, 63-68.

(19) Phillips, D. P.; Gao, W.; Yang, Y.; Zhang, G.; Lerario, I. K.; Lau, T. L.; Jiang, J.; Wang, X.; Nguyen, D. G.; Bhat, B. G.; Trotter, C.; Sullivan, H.; Welzel, G.; Landry, J.; Chen, Y.; Joseph, S. B.; Li, C.; Gordon, W. P.; Richmond, W.; Johnson, K.; Bretz, A.; Bursulaya, B.; Pan, S.; McNamara, P.; Seidel, H. M. Discovery of trifluoromethyl(pyrimidin-2-yl)azetidine-2-carboxamides as potent, orally bioavailable TGR5 (GPBAR1) agonists: Structure-activity relationships, lead optimization, and chronic in vivo efficacy. J. Med. Chem. 2014, 57, 3263.

(20) Fryer, R. M.; Ng, K. J.; Nodop Mazurek, S. G.; Patnaude, L.; Skow, D. J.; Muthukumarana, A.; Gilpin, K. E.; Dinallo, R. M.; Kuzmich, D.; Lord, J.; Sanyal, S.; Yu, H.; Harcken, C.; Cerny, M. A.; Hickey, E. R.; Modis, L. K. G protein-coupled bile acid receptor 1 (GPBAR1) stimulation mediates arterial vasodilation through a KCa1.1 (BKCa)-dependent mechanism. J. Pharmacol. Exp. Ther. 2014, 348, 421-431.

(21) Högenauer, K.; Arista, L.; Schmiedeberg, N.; Werner, G.; Jaksche, H.; Bouhelal, R.; Nguyen, D. G.; Bhat, B. G.; Raad, L.; Rauld, C.; Carballido, J. M. G-Protein-Coupled Bile Acid Receptor 1
(GPBAR1, TGR5) Agonists Reduce the Production of Proinflammatory Cytokines and Stabilize the Alternative Macrophage Phenotype. J. Med. Chem. 2014, 57, 10343-10354.

(22) Duan, H.; Ning, M.; Zou, Q.; Ye, Y.; Feng, Y.; Zhang, L.; Leng, Y.; Shen, J. Discovery of Intestinal Targeted TGR5 Agonists for the Treatment of Type 2 Diabetes. J. Med. Chem. 2015, 58, 3315-3328.

(23) Macchiarulo, A.; Gioiello, A.; Thomas, C.; Massarotti, A.; Nuti, R.; Rosatelli, E.; Sabbatini, P.; Schoonjans, K.; Auwerx, J.; Pellicciari, R. Molecular field analysis and 3D-quantitative structure-activity relationship study (MFA 3D-QSAR) unveil novel features of bile acid recognition at TGR5. J. Chem. Inf. Model. 2008, 48, 1792-801.

(24) Macchiarulo, A.; Gioiello, A.; Thomas, C.; Pols, T. W. H.; Nuti, R.; Ferrari, C.; Giacchè, N.; De Franco, F.; Pruzanski, M.; Auwerx, J.; Schoonjans, K.; Pellicciari, R. Probing the Binding Site of Bile Acids in TGR5. ACS Med. Chem. Lett. 2013, 4, 1158-1162.

(25) Winterfeldt, E. Applications of diisobutylaluminium hydride (DIBAH) and triisobutylaluminium (TIBA) as reducing agents in organic synthesis. Synthesis 1975, 1975, 617-630.

(26) Agarwal, S.; Jain, M. R.; Patel, P. R. 2-Thio-Imidazole Derivatives as TGR5Modulators. PCT Int. Appl. WO 2013/054338, 18 April 2013 (Appl. PCT/IN2012/000471, 4.07.2012).

(27) Wang, Y.-D.; Chen, W.-D.; Yu, D.; Forman, B. M.; Huang, W. The G-Protein-coupled bile acid receptor, Gpbarl (TGR5), negatively regulates hepatic inflammatory response through antagonizing nuclear factor kappa light-chain enhancer of activated B cells (NF- $\kappa \mathrm{B})$ in mice. Hepatology 2011, 54, 1421-1432.

(28) Schmidt, S.; Gonzalez, D.; Derendorf, H. Significance of protein binding in pharmacokinetics and pharmacodynamics. J. Pharm. Sci. 2010, 99, 1107-1122.

(29) Bell, R. H.; Hye, R. J. Animal models of diabetes mellitus: physiology and pathology. J. Surg. Res. 1983, 35, 433-460.

(30) Shafrir, E. Animal models of non insulin dependent diabetes. Diabetes/Metab. Rev. 1992, 8, 179-208. 